\title{
PERAN JARINGAN SOSIAL PADA KAMPANYE LINGKUNGAN DI MEDIA SOSIAL: KASUS KAMPANYE MELAWAN ASAP
}

\author{
Ika Hariyani \\ Departemen Sosiologi Universitas Indonesia \\ ikahariyani@gmail.com
}

\begin{abstract}
Campaigns nowadays are oftenly carried through social medias, including campaigns concerning the environment. This paper views environmental campaign in social medias could be effective if viewed from another side, that is social network. This study sees how social network can improve the effectivity of environmental campaigns in social medias, therefore it's safe to say that this study brings an addition to previous studies related to factors that influenced the effectivity of environmental campaigns that utilized social medias as a channel of communication. The method used for this paper is qualitative method, with case study on Melawan Asap (Fight the Haze) campaign initiated by BEM UI (Executive Board of Students of University of Indonesia) in 2015 to form an alliance consisting several organizations from inside and outside of the university. The result shows that the involvement of networks in social media affects the effectivity of Fight the Haze campaign. Also, the social relation between organizations that are united under the alliance of Fight the Haze campaign are based on sentimental network.
\end{abstract}

\begin{abstract}
Abstrak
Kampanye kian marak dilakukan dengan menggunakan media sosial, tidak terkecuali kampanye lingkungan. Tulisan ini melihat kampanye lingkungan di media sosial dapat efektif dari sisi lain yaitu dari jaringan sosial. Kajian ini melihat bagaimana jaringan sosial berperan dalam membuat efektif kampanye lingkungan di media sosial, sehingga dapat dikatakan bahwa kajian ini menambahkan penemuan dari kajiankajian sebelumnya yang berbicara mengenai faktor yang membuat efektif kampanye lingkungan dengan menggunakan media sosial sebagai media komunikasinya. Metode yang digunakan dalam tulisan ini adalah metode kualitatif dengan studi kasus pada kampanye melawan asap yang diinisiatori oleh BEM UI 2015 untuk membentuk sebuah aliansi dengan menggandeng beberapa organisasi di UI dan juga dari luar UI. Hasil kajian ini menunjukkan bahwa keterlibatan peran jaringan di media sosial mempengaruhi efektifitas kampanye melawan asap, serta hubungan sosial antar organisasi yang tergabung dalam aliansi gerakan melawan asap terbentuk berdasarkan jaringan perasaan/sentiment.
\end{abstract}

Keywords: Social Network, Environmental Campaign, Social Media 


\section{PENDAHULUAN}

Media sosial dianggap cukup efektif untuk mendukung kampanye lingkungan hidup (Syamsul, 2014). Di Indonesia sendiri kampanye dengan menggunakan media sosial telah banyak dilakukan seperti halnya kampanye yang dilakukan oleh @ EHIndoneisa dan Earth Hour Solo.Kampanye \#PlastikTakAsik yang dilakukan oleh akun @ EHIndoneisa didukung oleh ribuan orang relawan individu dan komunitas selain itu. Aksi tersebut dilakukan serentak di 23 kota, dari aksi tersebut membuat para relawan semakin sadar akan dampak negatif akibat sampah plastik yang selama ini digunakan dan resikonya untuk generasi mendatang (Antara News, 23 Februari 2014). Aksi lainnya yang dilakukan oleh Earth Hour Solo yaitu mematikan lampu selama 6o menit di kota Solo. Aksi ini terbukti efektif ditandai dengan semakin meningkatnya relawan yang mendaftar untuk turut mengkampanyekan gaya hidup ramah lingkungan. Setelah tahun ke 2 aksi tersebut berjalan di Kota Solo, sudah mencapai zooan relawan, dimana relawan ini berperan sebagai pemberi contoh kampanye gaya hidup ramah lingkungan kepada masyarakat luas (Widorini, 2014). Lalu sebenarnya hal apa yang membuat kampanye lingkungan efektif dengan menggunakan media sosial sebagai media komunikasinya?

Beberapa hasil penelitian sebelumnya menunjukkan faktor-faktor yang membuat kampanye lingkungan dengan menggunakan media sosial dapat efektifsalah satunya karena adanya sosialisasi tambahan yang dilakukan komunitas tersebut secara langsung. Jadi selain memaksimalkan media online untuk kampanye lingkungannya, komunitas juga melakukan sosialisasi secara offline (Widorini, 2014; Octavianti, 2014; Lailia, 2014).Selain itu, Loisa (2011) mengungkapkan bahwa faktornya adalah karena adanya administrator online yang menggerakkan kampanye lewat media sosial tersebut bekerja secara aktif.Sedangkan Kapriani dan Lubis (2014) berpendapat bahwa faktor faktor yang membuat kampanye di media sosial berjalan dengan efektif karena keterlibatan followers di media sosial.
Faktor-faktor mengenai keefektifan kampanye lingkungan dengan memanfaatkan media sosial tidak terbatas pada halhal tersebut. Akan tetapi, menurut penulis terdapat faktor lainnya yaitu justru faktor yang datang dari peran jaringan sosial.Penulis melihat bahwa jaringan sosial yang dimiliki dapat berperan sebagai aktor penyebar konten kampanye lingkungan yang sedang dijalankan. Penulis berasumsi bahwa dengan semakin tersebar luasnya kampanye tersebut maka semakin banyak juga masyarakat yang terpapar akan kampanye yang dilakukan, dan memungkinkan semakin besarnya kesempatan untuk membuat kampanye tersebut efektif. Darsono (2011) juga menyatakan bahwa jaringan kerjasama yang terjalin antar organisasi yang terbentuk dapat bersifat saling mendukung dan melengkapi satu sama lain, terlebih ketika terjadi koalisi antar organisasi jika terdapat division of labour maka anggota koalisi dapat saling membantu serta menjalankan fungsi dan perannya sesuai dengan keahlian yang mereka miliki.

\section{METODE}

Penelitian ini menggunakan metode penelitian kualitatif. Alasan pemilihan metodekualitatifdalamartikeliniadalahstudi mengenai peran jaringan sosial memerlukan penggalian data secara detail agar penulis dapat memahami kasustersebut sehingga dapat memberi arti pada data yang telah didapatkan . Tipe Penelitian ini termasuk dalam penelitian studi kasus.Penelitian studi kasus adalah studi yang mengeksplorasi suatu masalah dengan batasan terperinci, memiliki pengambilan data yang mendalam, menyertakan berbagai sumber informasi, dibatasi oleh waktu dan tempat, dan kasus yang dipelajari berupa program, peristiwa, aktivitas, atau individu (Sistarwanto, 2010). Kasus yang dipilih penulis dalam artikel ini adalah kampanye melawan asap.

Teknik yang dilakukan dalam pengambilan data di lapangan adalah dengan melakukan wawancara mendalam. Informan yang menjadi sumber data utama dalam 
penelitian ini adalah kepala Departemen Lingkungan Hidup BEM UI 2015.Informan tersebut dipilih berdasarkan penguasaan dan keaktifan informan dalam aksi-aksi lingkungan yang digawanginya dibawah lembaga Badan Eksekutif Mahasiswa. Untuk lebih memperkaya data, selanjutnya penulis menggunakan teknik snowball. Dengan teknik ini, penulis meminta rekomendasi informan selanjutnya untuk dilakukan wawancara terkait dengan informasi yang diinginkan dan berdasarkan kriteriakriteria yang penulis tetapkan.Informan ke-2 adalah salah satu staf Kastrat (kajian dan aksi strategis) serta menjabat juga sebagai koordinator Siaga (singa-singa pergerakan) FISIP UI.Informan ke-3 adalah PO (project officer) dari konser amal jingga peduli Rijantan. Selain itu, penulis juga melakukan observasi terhadap akun media sosial departemen lingkungan hidup BEM UI 2015(@BEMUI_Gogreen) dan akun @ jinggapeduli (akun miliki BEM FISIP untuk melakukan gerakan-gerakan) berkenaan dengan kampanye melawan asap. Observasi akun media sosial tersebut dilakukan dengan menggunakan situs klear.com.Layanan klear. com yang dahulunya bernama Twtrland merupakan platform untuk menganalisis profil pengguna twitter. Dari platform tersebut penulis mendapatkan gambaran aktivitas yang dilakukan akun twitter @ BEMUI_Gogreen berdasarkan postingan per minggu, like dan retweet di setiap post, sehingga hal ini dapat memudahkan penulis terlebih saat penulis ingin mengakses postingan @BEMUI_Gogreen yang telah lampau.

\section{KERANGKA KONSEP}

Dalam tulisan ini, penulis menggunakan konsep jaringan sosial. Menurut Van Poucke (dalam Lukito 1995: 9-11), bila ditinjau dari tujuan hubungan sosial yang membentuk jaringan-jaringan sosial yang ada dalam masyarakat, dapat dibedakan ke dalam 3 tipe jaringan sosial, yaitu:

1) Jaringan perasaan/sentimen, yang terbentuk dari hubungan-hubungan sosial di mana hubungan sosial tersebut menjadi tujuan dari tindakan sosial, misalnya pertemanan, percintaan, kekerabatan dan sejenisnya. Struktur yang dibentuk oleh hubungan jaringan sentiment ini cenderung lebih permanen. Konsekuensinya adalah mekanisme yang menjamin stabilitas struktur sosial yang tercipta sehingga hubungan- hubungan sosial ini dinilai semacam norma-norma yang dapat membatasi tindakan sosial yang cenderung mengganggu kepermanenan struktur jaringan yang bersangkutan. Terdapat sejumlah kompleks nilai-nilai dan norma-norma yang ditegakkan atas struktur hubungan guna memelihara keberlangsungannya. Hubungan-hubungan sosial yang terwujud cenderung menjadi hubungan yang dekat dan menyatu. Hal ini yang menyebabkan adanya saling kontrol yang relatif kuat antar pelaku dalam jaringan sosial tipe ini, sehingga memudahkan lahirnya nilai-nilai dan norma-norma yang mengembangkan kontinuitas yang relatif stabil terhadap pola-pola jaringan. Akibatnya, jaringan tipe ini menghasilkan suatu rasa solidaritas, artinya para pelaku cenderung mengurangi kepentingan-kepentingan pribadinya.

2) Jaringan kepentingan/interest, jaringan ini terbentuk oleh hubungan-hubungan yang bermakna pada tujuan-tujuan tertentu atau khusus. Bila tujuan tersebut spesifik dan konkrit (seperti memperoleh pekerjaan, barang atau jasa), setelah tujuan-tujuan tersebut tercapai maka hubungan-hubungan ini biasanya tidak berkelanjutan.Struktur yang muncul dari tipe jaringan ini adalah sebentar dan berubah-ubah.Tindakan dan interaksi dievaluasi berdasarkan tujuan relasional. Namun, bila tujuan tersebut tidak sekonkrit dan spesifik atau tujuan- tujuan hampir selalu berulang maka struktur yang terbentuk adalah relatif stabil atau permanen.

3) Jaringan kekuasaan/power, dalam tipe jaringan ini konfigurasi-konfigurasi saling keterhubungannya dibentuksecara sengaja atau diatur. Jaringan kekuasaan 
ini terbentuk bila pencapaian tujuan -tujuan pelaku membutuhkan tindakan kolektif, dan biasanya dibuat permanen (misalnya organisasi formal-perusahaan, pemerintahan dansejenisnya). Hubunganhubungan kekuasaan biasanya ditujukan pada penciptaan kondisi-kondisi yang dibutuhkan untuk mencapai tujuantujuan jangka panjang atau umum. Unit sosialnya bersifat artifisial yang direncakan atau distrukturkan secara sengaja oleh power.Tipe jaringan ini harus mempunyai pusat kekuasaan/ power, yang secara terus menerus mereview penampilan organisasi dan mempolakan kembali strukturnya untuk peningkatan efisiensinya.Dalam hal ini, kontrol informal tidak memadai, karena masalah yang ada jauh lebih kompleks dibanding jaringan sosial yang terwujud secara alamiah.Jaringan kekuasaan/ power ini membutuhkan distribusi penghargaan dan sanksi yang terstruktur secara formal guna menyokong timbulnya kerelaan denganperaturan-peraturan dan perintah-perintah oleh pusat- pusat kekuasaan/power mereka.

Terkait keefektifan kampanye dengan menggunakan media sosial, pengukuran efektivitas setiap kegiatan kehumasan baik yang dilakukan secara offline maupun online harus didasarkan pada tujuan yang telah ditetapkan. Hal ini dikarenakan suatu kegiatan kehumasan hanya dikatakan berhasil bila tujuan kegiatan tersebut tercapai (Ardianto, 2001). Selain itu, penulis juga menggunakan pengukuran efektivitas kampanye di media sosial berdasarkan aspekaspek dari Solis (2011:326) sebagai berikut: (1) Exposure, untuk mengetahui terpaan (exposure) yang menunjukkan sejauh mana perusahaan, merek atau organisasi berhasil menciptakan eksposur isi dan pesan melalui saluran media sosial. Pengukuran dilakukan berdasarkan banyaknya audience yang terpapar oleh konten kampanye yang diciptakan. Pengukuran ini dapat dilihat melalui jumlah hit atau visit pada website, followers pada twitter, fans pada facebook, ataupunpada video di Youtube dan pada postingandiblog. (2) Engagement, padaaspek ini mengukur lebih jauh mengenai seberapa banyak tindakan yang diambil pada pesan atau kampanye yang dibuat. Pengukuran dapat dilihat dari jumlah link yang di klik, like dan komentar di media sosial, serta postingan blog yang di share ke media sosial. (3) Influence, mengukur sejauh mana konten media sosial organisasi mempengaruhi persepsi dan sikap audience. Sejauh mana konten yang kita kampanyekan dianggap positif, netral atau justru negatif.Pada aspek ini pengukurannya dapat dilihat melalui berapa banyak audiens yang persepsinya berhasil diubah berkat kampanye. (4) Action, aspek yang diukur sudah mencapai tataran perilaku, misal audience yang merekomendasikan kampanye tersebut pada audience lain.

Menurut Dube dalam Lesmana (2012), terdapat lima karakteristik dasar dari media sosial. Karakteristik tersebut antara lain:

a. User-based : media sosial online dibangun dan diarahkan oleh pengguna sendiri. Tanpa pengguna media akan menjadi ruang kosong diisi dengan forum kosong, aplikasi dan chat room. Pengguna mengisi media dengan percakapan dan konten.Arah konten ditentukan oleh user yang terlibat dalam diskusi.Inilah yang membuat media sosial jauh lebih menarik dan dinamis bagi pengguna internet.

b. Interactive : karakteristik lain dari media sosial modern adalah kenyataan bahwa merekabegituinteraktif. Ini berarti bahwa media sosial bukan hanya kumpulan chat room dan forum lagi.Mereka bisa berbagi foto dan video melalui media sosial ini. Media sosial ini dengan cepat menjadi hobi karena lebih dari sekedar hiburan.

c. Community-driven : media sosial yang dibangun dan berkembang dari konsepkonsep komunitas. Ini berarti bahwa sama seperti komunitas atau kelompok sosial di seluruh dunia yang didirikan pada kenyataan bahwa anggota memegang keyakinan atau hobi yang sama, dan memiliki banyak kesamaan di antara komunitas tersebut. 
d. Relationships : Tidak seperti website, media sosial berkembang pesat dengan menitikberatkan pada relationship. Hubungan yang lebih kuat terjadi dalam jaringan. Bila kita melakukan post atau update pada halaman tersebut, maka penyebaran konten di seluruh jaringan kontak dan sub- kontak jauh lebih besar dari yang kita sadari.

e. Emotion over content : karakteristik lain yang unik dari media sosial adalah faktor emosional. Website dimasa lalu difokuskan terutama pada penyediaan informasikepadapengunjung, sedangkan media sosial membuat pengguna terlibat secara emosional tentang konten yang terdapat dalam media sosial.

\section{Kampanye Melawan Asap}

Kabut asap yang melanda beberapa wilayah Sumatera dan Kalimantan Indonesia menjadi keprihatinan bersama. Per tanggal 11 September 2015 berdasarkan pantauan satelit terra dan aqua terdapat 1.887 titik panas yang diantaranya 575 di Sumatera dan 1.312 di Kalimantan (British Broadcasting Corporation (BBC) Indonesia, 11 September 2015). Kabut asap ini diakibatkan dari aktivitas illegal perusahaan-perusahaan yang tidak bertanggung jawab dengan melakukan pembakaran hutan dan pengeringan lahan gambut guna merealisasikan kepentingan mereka yaitu membuka lahan perkebunan kelapa sawit dan kayu. Aktivitas ilegal ini dilakukan oleh perusahaan-perusahaan besar yang menghasilkan produk-produk seperti tissue, kertas, margarin, mentega, sampo, dan juga sabun yang notabene kita gunakan sehari-hari. Kabut asap ini menyerang ke beberapa daerah di Indonesia seperti Riau, Jambi, Sumatera Selatan, dan juga Kalimantan. Dari kabut asap tersebut membuat anak-anak tidak dapat sekolah, aktivitas terhambat, terjangkitnya penyakit pernafasan dan juga penyakit kulit.

Dengan semakin merajalelanya kabut asap akibat pembakaran hutan membuat beberapa organisasi kampus maupun organisasi lingkungan tergerak untuk membantu menanggulangi kasus ini, baik secara vertikal yang hubungannya terkait dengan pemerintah seperti melakukan advokasi, maupun secara horizontal yang berhubungan dengan membantu para korban kabut asap seperti memberikan bantuan berupa dana maupun barang-barang. Di UI terdapat sekumpulan organisasi mahasiswa dan aktivis lingkungan yang tergabung dalam aliansi gerakan melawan asap. Aliansi ini bermula dari kepedulian beberapa organisasi mahasiswa seperti BEM UI, BEM FISIP UI, BEM FIB UI, HIMAKRIM (himpunan mahasiswa kriminologi) UI, SIAGA (singasinga pergerakan) FISIP UI, HIMAJA (himpunan mahasiswa Jambi) UI, KEMAS (keluarga mahasiswa sriwijaya) UI, dan juga IMR (ikatan mahasiswa Riau) terhadap isu asap. Awalnya masing-masing dari organisasi mahasiswa tersebut berjalan sendiri-sendiri untuk melancarkan aksi mereka. Namun, akhirnya BEM UI tergerak untuk mewadahi persatuan beberapa organisasi tersebut yang dilatarbelakangi dengan kepedulian akan isu yang sama. Pihak BEMUI percaya bahwasanya ketika ingin mendapatkan impact yang besar kita juga harus menciptakan kolaborasikolaborasi agar dapat mengoneksikan dotsdots yang ada.

Selain menyatukan beberapa organisasi mahasiswayangada diUI dengan membentuk aliansi, BEM UI juga mengajak beberapa organisasi lingkungan seperti Greenpeacedan WALHI untuk bergabung di aliansi tersebut. BEM UI tentunya memiliki pertimbangan tersendiri dengan mengajak kedua organisasi lingkungan ini, pertimbangan tersebut yaitu selain memiliki kesamaan fokus isu yang diangkat yaitu terkait asap, kedua organisasi ini juga memiliki dedikasi yang tinggi terhadap isu-isu lingkungan, totalitas dalam menyebarkan kampanyekampanye lingkungan, dan nilai tambahnya adalah pengikut di media sosial organisasi lingkungan ini sudah cukup banyak sehingga dapat membantu mengefektifkan kampanye melawan asap dari aliansi gerakan melawan asap.

Terdapat tiga ranah gerakan yang disepakati dalam aliansi gerakan melawan 
asap. Tiga ranah tersebut antara lain: (1) Ranah Kampanye dan Edukasi. Organisasi yang fokus pada ranah ini adalah BEM UI yang diwakili dari Departemen Lingkungan Hidup, Greenpeace, Himaja, Kemas dan IMR. (2) Ranah Advokasi. Ranah ini lebih berupa melakukan kajian dan diskusi publik. Organisasi yang lebih fokus pada ranah ini adalah BEM FIB UI, WALHI, dan HIMAKRIM yang diwakili oleh WPC (We Prevent Crime). (3) Ranah Donasi. Melakukan pengumpulan dana dari mahasiswa se-UI dan juga masyarakat umum. Organisasi yang lebih fokus pada ranah ini adalah BEM FISIP UI, dan SIAGAFISIP UI. Pembagian ke dalam tiga ranah ini didasarkan pada aksi-aksi yang sebelumnya telah mereka jalankan oleh masing-masing organisasi sebelum terbentuknya aliansi gerakan melawan asap.

Dapat dikatakan bahwa aturan yang terbentuk dalam aliansi gerakan melawan asap bersifat cair. Hal ini terlihat ketika masing-masing organisasi dalam melakukan aksi mengalami tumpang tindih atau mengalami perpotongan ranah antara ranah satu dengan ranah lainnya. Misalnya saja aksi yang dilakukan BEM UI, pada kesepakatan di awal gerakan-gerakan yang dilakukan BEM UI lebih terfokus untuk menggalakkan kampanye-kampanye baik yang dilakukan melalui media sosial (online) ataupun aksi yang dilakukan secara langsung (offline). Namun, pada kenyataannya BEM UI pun melakukan kegiatan penjualan masker kepada masyarakat umum yang mana hal ini seharusnya dilakukan oleh organisasi di ranah donasi, sehingga pihak BEM UI sebenarnya bergerak di dua ranah sekaligus, yaitu pada ranah kampanye dan juga ranah donasi. Gerakan yang dilakukan BEM UI tersebut dapat dikatakan tidak sesuai dengan aturan, namun hal tersebut justru dianggap positif bukan suatu hal yang menyimpang karena dapat membantu kerja dari organisasi yang bertanggungjawab pada ranah donasi.

Dalam tulisan ini, penulis hanya melihat beberapa peran organisasi yang dianggap memiliki peran yang kuat dalam meningkatkan efektifitas kampanye pada aliansi melawan asap di media sosial. Media social menjadi penting untuk dilihat karena sejalan dengan Lesmana (2012), bahwa di zaman sekarang ini dengan memanfaatkan media sosial dapat mengajak siapa saja yang tertarik untuk berpartisipasi dengan memberi kontribusi dan feedback secara terbuka, memberi komentar serta membagi informasi dalam waktu yang cepat dan tak terbatas. Peran organisasi yang dibahas dalam tulisan ini diantaranya peran BEM UI, Greenpeace, dan BEM FISIP UI.Penentuan terhadap ketiga organisasi yang berperan kuat tersebut dipilih agar penulis dapat melihat peran yang dilakukannya secara lebih mendalam.

\section{HASIL DAN PEMBAHASAN}

\section{Peran BEM UI dan Greenpeace}

Berdasarkan kesepakatan terkait tiga ranah dalam aliansi gerakan melawan asap, BEM UI bertanggung jawab pada ranah kampanye. BEM UI menyebarkan kampanye melawan asap di media sosial (online) dan juga melakukan aksi kampanye secara langsung (offline). Namun dalam tulisan ini yang menjadi fokus untuk dilihat lebih jauh adalah kampanye yang dilakukan secara online di media sosial. Kampanye yang dilakukan secara online disebarluaskan melalui kanal media sosial seperti twitter dan line. Pemilihan media twitter dan line didasarkan atas tren penggunaan media sosial yang lebih sering digunakan oleh mahasiswa UI, karena memang target utama dari kampanye melawan asap adalah mahasiswa UI.

Dalam melakukan kampanye melawan asap di media sosial, BEM UI memiliki beberapa strategi, seperti menggunakan hashtag berupa \#melawanasap. Hal ini dilakukan agar semakin tersebarluasnya kampanye melawan asap ke orang banyak. Selain itu juga untuk mempermudah mahasiswa UI ataupun masyarakat umum dalam melakukan pencarian tentang kampanye melawan asap dapat dengan hanya mencarihashtagtersebutdikolompencarian. Hal ini yang menjadi kelebihan dari media sosial dimana pengguna tidak harus susah 
payah dalam mencari postingan orang lain dengan menelusurinya satu persatu, mereka dapat dengan mudah menuliskan hashtag tertentu dan dengan menunggu beberapa detik akan muncul semua yang berkaitan dengan hashtag tersebut. Menurut Dube dalam Lesmana (2012) disebut dengan istilah relationships dalam karakteristik media sosial dimana orang lain dengan mudah mencari post atau update dari akun orang lain, dan seketika konten tersebar dengan penggunaan hashtag tersebut. Terlebih ketika hashtag yang diciptakan dapat menjadi trending topic maka dengan mudah seluruh jaringan kontak yang kita miliki maupun yang tidak kita miliki di media sosial akan terpapar konten kampanye yang kita ciptakan sehingga berdampak pada lebih besarnya netizen yang mengetahui kampanye tersebut. Namun, kampanye melawan asap ini belum bisa menembus daftar trending topic di twitter.

Strategi lainnya adalah BEM UI memiliki alur penyebaran kampanye di media sosial. Alur kampanye ini dilakukan secara bertahap, tahap awal BEM UI hanya mengeluarkan kata-kata, gambar atau video singkat yang hanya memberikan sedikit informasi dari kampanye melawan asap, hal ini dijadikan sebagai pemicu di media sosial dengan tujuan untuk membangun kesadaran para netizen. Kesadaran para netizen dapat ditandai dengan respon yang diberikan pada postingan pemicu tersebut. Setelah netizen dianggap telah sadar bahwa BEM UI akan melakukan suatu aksi tertentu, tahap selanjutnya adalah memposting kampanye melawan asap. Akun BEM UI pun menandai (tag) beberapaakun BEM se-UI, dan jugaakun komunitas lingkungan seperti FKH (Forum Komunitas Hijau) Depok agar kampanye melawan asap semakin tersebar luas di media sosial. Hal ini juga yang menjadi kelebihan lainnya dengan memanfaatkan media sosial, Dube dalam Lesmana (2012) menyebutnya sebagai karakteristik interactive, dimana para pengguna media sosial tersebut tidak hanya melakukan chatting untuk membicarakan suatu hal, bahkan mereka dapat berbagi foto dan juga video tentang suatu keonten dalam hal ini kampanye melawan asap di media tersebut, dengan begitu dapat menarik minat para netizen untuk ikut dalam aksi melawan asap karena mereka tidak hanya melihat berupa kata-kata tapi juga informasi dan ajakan dalam bentuk gambar maupun video.

BEM UI juga tidak hanya melakukan kampanye secara online di media sosial namun juga melakukan kampanye secara langsung. Kampanye ini dilakukan pada 21 September 2015 dengan titik aksi di Bundaran Hotel Indonesia.Massa dimobilisasi oleh BEM UI dari kampus UI menggunakan biskuning UI, dengan titik keberangkatan di halte FISIP UI. Agenda yang direncanakan tidak hanya melakukan kampanye semata namun juga melakukan penggalangan donasi dari penjualan masker.

Kampanye yang dilakukan BEM UI di media sosial tentunya tidak lepas dari peran Greenpeace Indonesia. Terdapat kesepatakan bersama mengenai pembagian peran antara BEM UI dan Greenpeace Indonesia dalam melakukan kampanye ini. Greenpeace dalam hal ini berperan sebagai pemberi informasi secara langsung dari titik asap ke pihak BEM UI. Pemberian informasi dari pihak Greenpeace di titik asap dilakukan setiap saat, apabila ada perkembangan terbaru di lapangan, pihak Greenpeace langsung segera mungkin mengabarkan perkembangan tersebut ke pihak BEM UI. Lalu pihak BEM UI bertanggungjawab dalam hal publikasi ke media sosial, BEM UI bertugas mengemas informasi yang telah didapatkan secara aktual dari pihak Greenpeace di titik asap dan memvisualisasikan informasi tersebut di semua akun media sosial yang BEM UI miliki.

Tidak terdapat norma yang secara khusus mengatur kerjasama yang dilakukan antara BEM UI dan Greenpeace Indonesia. Sehingga kerjasama yang dilakukan hanya berpegang pada nilai-nilai kesepakatan bersama, seperti kesepakatan pembagian tugas, kesepatan untuk berada dalam satu aliansi yaitu aliansi gerakan melawan asap. Dengan berpegang pada kesepatan yang ada baik BEM UI maupun Greenpeace Indonesia dapat menjaga attitude satu sama lain, 
seperti tidak membuat kecewa salah satu pihak dalam hubungan kerjasama tersebut.

Jika merujuk pada Van Poucke, hubungan sosial yang terjadi antara BEM UI dan Greenpeace dapat dilihat sebagai jaringan perasaan/sentiment, karena hubungan sosial yang timbul adalah kepedulian yang sama terhadap isu asap. Hubungan sosial ini menjadi tujuan dari tindakan sosial yang dilakukan secara bersama antara BEM UI dan Greenpeace berupa menyebarkan kampanye melawan asap di media sosial. Sebelum tergabung dalam aliansi gerakan melawan asap, telah terdapat hubungan sosial antara Greenpeace dan BEM UI, seperti halnya ketika BEM UI memperingati hari lingkungan hidup, pihak Greenpeace memberikan dukungannya seperti melakukan retweet di media sosial. Pun sebaliknya BEM UI memberikan dukungannya kepada pihak Greenpeace dengan melakukan retweet pula pada postingan Greenpeace.

Setelah menjadi bagian dari aliansi gerakan melawan asap hubungan perasaan/ sentiment tersebut menjadi lebih dekat, hal ini karena terdapat kepedulianyang sama dan terjadi interaksi yang lebih sering tentang aksi melawan asap. Interaksi yang lebih sering ditandai dengan adanya kerjasama antar aktor dengan pembagian tugasnya masing-masing, hal ini sejalan dengan data di lapangan, pihak Greenpeace memberikan informasi aktual dari titik asap dan pihak BEM UI menerima informasi tersebut, dari proses demikian telah terjadi interaksi yang intensif antara BEM UI dan Greenpeace, sehingga dapat dikatakan hubungan perasaan/sentiment antar aktor menjadi semakin dalam.

Berdasarkan pengamatan selama penelitian, hubungan yang telah terbina antara BEM UI dan Greenpeace dapat dilihat bahwa muatan sosial yang paling kuat didasarkan pada hubungan "kegiatan kepedulian lingkungan”. Karena hubungan ini didasarkan pada minat atau kepedulian terhadap lingkungan, ikatan emosi terkait dengan melawan asap mengikat hubungan mereka sehingga menghasilkan rasa solidaritas, dengan artian para aktor
(Greenpeace dan BEM UI) cenderung mengurangi kepentingan-kepentingan pribadinya dan menjunjung kepentingan bersama akan kampanye melawan asap.

Dengan bermuatan hubungan perasaan/ sentiment terhadapisuyang samadarigerakan melawan asap juga membuat satu sama lain baik Greenpeace maupun BEM UI menjadi total dalam menjalankan tugasnya masingmasing, bahkan sampai membuat salah satu dari mereka terlihat kewalahan dalam menjalankan tugasnya. Hal ini terlihat ketika pihakGreenpeacesecaraintensifmemberikan update informasi tentang kondisi asap dari titik asap, sedangkan di sisi lain pihak BEM UI sendiri merasa kewalahan untuk menyajikan informasi- informasi tersebut di media sosial karena BEM UI menganggap kurangnya sumberdaya manusia yang BEM UI miliki untuk menyajikan informasiinformasi yang diberikan sangat intensif oleh Greenpeace. Sehingga hal ini disadari menjadi salah satu kelemahan internal yang BEMUI rasakan selama melakukan kerjasama dengan Greenpeace di bawah aliansi gerakan melawan asap.

Respon yang diberikan oleh netizen di twitter berupa me- retweet pada kampanye melawan asap yang disebarkan di akun @ BEMUI_GOgreen total hanya sebanyak 14 retweet selama melakukan kampanye 3 Bulan. Hal ini pun diakui oleh pihak BEM UI sebagai kendala dalam melakukan penyebaran kampanye di media sosial karena perlahan twitter telah mulai ditinggalkan, khususnyaoleh mahasiswa UI. Media sosial yang sedang digandrungi oleh netizen sekarang ini berdasarkan pada pihak divisi humas BEM UI yaitu facebook dan juga line.Namun, khususnya mahasiswa UI sebenarnya lebih ke media line dibanding facebook (wawancara dengan Fania dari BEM UI, 8 Oktober 2015). Dengan melihat pada followers dari akun BEM UI, dapat dikatakan bahwa sebanyak 4.90oan akun yang terpapar dari kampanye melawan asap di Line, respon yang diberikan di media Line terhadap kampanye melawan asap dari akun BEM UI, yang melakukan share sebanyak 130 akun sedangkan yang like kampanye tersebut 
sebanyak 141 akun.

\section{Peran BEM FISIP dan Siaga FISIP UI}

BEM FISIP UI menjadi salah satu anggota dari aliansi melawan asap. Keikutsertaan BEM FISIP UI dalam aliansi ini didasarkan pada tujuan yang samaberkenaan dengan kepeduliannya terhadap korban-korban asap yang diakibatkan dari terbakarnya beberapa titik hutan di wilayah Indonesia. BEM FISIP UI sendiri dalam aksi melawan asap lebih fokus pada ranah yang ketiga yaitu ranah donasi. Hal ini dikarenakan divisi sosial masyarakat (sosmas) yang mewakili BEM FISIP UI pada aksi melawan asap. Namun, saat melakukan penggalangan dana punBEM FISIP UI tidak terlepas untuk menyelipkan kampanye-kampanye tentang melawan asap agar semakin banyak juga mahasiswa yang terpapar dengan kampanye melawan asap. Dalam melakukan aksi ini BEM FISIP UI melakukan kerjasama dengan SIAGA FISIP UI dalam menggalang dana dan melakukan kampanye. Hal ini dikarenakan koordinator SIAGA merupakan salah satu staf di BEM FISIP UI serta isu melawan asap menjadi kepedulian dari SIAGA FISIP juga.

Terdapat beberapatahapanyang dilakukan dalam melakukan penggalangan dana oleh BEM FISIP UI dan SIAGA FISIP. Tahapan tersebut antara lain: mula-mula mereka memasang poster dan pamflet-pamflet tentang kebakaran hutan, korban asap, yang di pasang di seluruh koridor FISIP dan juga di media sosial yang mereka miliki. Hal ini bertujuan memberi penuansaan bahwa BEM FISIP dan SIAGA FISIP akan melakukan suatu gerakan, khususnya gerakan peduli terhadap korban asap. Sehingga membuat mahasiswa sadar dan ikut bergerak, baik memberikan bantuan secara fisik ataupun memberikan sumbangan secara materi dalam gerakan melawan asap.

Tahap selanjutnya, mereka melancarkan donasi dengan menyisipkan amplop di setiap absen kelas dengan tujuan mendapatkan dana dari semua mahasiswa FISIP tanpa perlu mendatangi satu persatu kelas yang ada di FISIP. Setelah menyebar amplop di setiap kelas dan juga melakukan penuansaan dari gerakan melawan asap, puncak gerakannya yaitu pada konser amal jingga peduli Rijantan. Selama konser berlangsung pihak panitia juga mengedarkan kotak di takor (taman korea) untuk mengumpulkan sumbangan yang lebih banyak lagi.

Konser amal jingga peduli RIJANTAN didanai oleh BEM FISIP dan SIAGA FISIP. Dana tersebut disatukan oleh mereka, lalu dijadikan sebagai dana awal untuk membuat konser. Konser ini diadakan di Taman Korea (Takor), yang dimulai dari pukul 19.0o WIB sampaiselesai.Konserinimempersembahkan penampilan dari Inner Light, komunitas music FISIP (KMF), Musisi Jalan "Eka”, Bengkel Kreasi Seni Teknik, institute music jalanan, dan terdapat sesi sharing antara BEM FISIP UI, BEM UI, HIMAJA (himpunan mahasiswa Jambi), dan IMR (ikatan mahasiswa Riau) UI serta melakukan doa bersama dengan organisasi keagamaan yaitu FSI (Forum Studi Islam), PO (Persekutuan Oikumene) dan KUKSA (Kesatuan Umat Katolik Sivitas Akademika).

Dana yang didapatkan dari konser amal jingga peduli Rijantan, amplop yang diselipkan di kelas, dan juga kotak yang diedarkan di takor didapatkan total dana sebesar lebih kurang 4 juta. Dana tersebut diserahkan ke aliansi melawan asap untuk nantinya disatukan dengan donasi-donasi yang diberikan dari organisasi lain ataupun masyarakatumumyang memberikan transfer dana ke pihak aliansi gerakan melawan asap. Kelemahan BEM FISIP dan SIAGA FISIP berkenaan dengan dana ini adalah mereka tidak mengetahui alur berjalannya dana donasi yang telah didapatkan aliansi gerakan melawan asap padahal BEM FISIP dan SIAGA FISIP merupakan salah satu bagian dari aliansi gerakan melawan asap di ranah yang ketiga yaitu ranah donasi.

Terdapat tantangan yang dirasakan oleh pihak BEM FISIP dan SIAGA FISIP dalam menggalang dana untuk gerakan melawan asap. Tantangannya yaitu terkait dengan waktu, karena memang musibah ini perlu bantuan dengan gerak yang cepat agar para korban asap dapat terbantu dengan segera sehingga hal ini menjadi tantangan untuk 
BEM FISIP dan SIAGA FISIP untuk dapat mempersiapkan acara dengan waktu yang sangat sempit. Mereka mempersiapkan konser tersebut hanya dengan waktu satu minggu.Selain itu, perizinan juga menjadi tantangan lainnya.Mengurus perizinan cukup menghabiskan waktu yang tidak sebentar. Karena walaupun BEM FISIP merupakan bagian dari FISIP namun dalam hal menggunakan fasilitas publik diperlakukan sama dengan mahasiswa FISIP lainnya.

Jika dilihat dari tujuan hubungan sosial yang terbentuk antara BEM FISIP UI dengan aliansi gerakan melawan asap dapat dikatakan bahwa terjadi interseksi hubungan sosial yang bermuatan perasaan/sentiment dan kepentingan. Di satu sisi kerjasama yang terjalin antara BEM FISIP dengan aliansi melawan asap tersebut berlandaskan pada keinginan untuk bersatu dan bergerak bersama dalam membantu korban asap (minat atau kepedulian yang sama terhadap lingkungan). Landasan tersebut menjadi tujuan dari tindakan sosial mereka. Hubungan- hubungan atau muatan sosial yang dibina karena memiliki kepedulian yang samaakan kondisi asap (lingkungan), dan dalam hubungan sosial perasaan yang timbul antara BEM FISIP dengan aliansi gerakan melawan asap membuat ikatan emosi antara satu dengan lainnya terbentuk. Ikatan emosi (berkenaan dengan lingkungan) yang mengikat hubungan menjadikan mereka menjadi satu kesatuan.Hubungan jaringan perasaan antara BEM FISIP dengan aliansi melawan asapmembuat adanya mekanisme kerja yang menjamin stabilitas hubungan antara keduanya. Mekanisme kerja ini dapat dilihat pada pembagian tanggungjawab atau pembagian peran di masing-masing ranah dalam aliansi gerakan melawan asap. Dari adanya mekanisme kerja tersebut timbul aturan-aturan yang membatasi tindakan sosial masing-masing aktor, namun yang penulis termukan di lapangan dalam kerjasama antara BEM FISIP dengan aliansi gerakan melawan asap aturan tersebut lebih bersifat cair dan tidak ada aturan secara tertulis yang mengatur tindakan sosial masing-masing aktor.
Selain hubungan perasaan/sentiment yang timbul dari tujuan hubungan sosial yang terbentuk, di sisi lain terlihat hubungan kepentingan yang juga timbul dari kerjasama yang terjalin antara BEM FISIP dengan aliansi melawan asap. Hubungan sosial yang terjalin antara BEM FISIP dengan aliansi melawan asap didasarkan pada tujuan tertentu yang ingin dicapai oleh BEM FISIP. Hal ini sejalan dengan apa yang penulis lihat terhadap beberapa hal pada kerjasama yang terjalin antara BEM FISIP dengan aliansi melawan asap, hal pertama seperti bidang dari pihak BEM FISIP yang terjun langsung adalah bidang sosial masyarakat padahal seharusnya bidang yang terlibat di aliansi melawan asap adalah bidang yang benarbenar concern terhadap lingkungan, hal ini terlihat kurang sesuai, sehingga terlihat terdapat hubungan yang "seperlunya", tidak heran jika BEM FISIP tidak mengetahui detail tentang dana donasi di aliansi melawan asap, seperti alur berjalannya dana donasi yang telah didapatkan oleh aliansi gerakan melawan asap, dan hal-hal detail lainnya. Dalam jaringan kepentingan dikatakanbahwa setelah tujuan tersebut tercapai biasanya hubungan tersebut tidak berkelanjutan.

Hal ini terlihat dari hubungan "seperlunya" yang timbul, artinya ketika tanggungjawab aktor tersebut telah selesai dalam hal ini BEM FISIP bertanggung jawab melakukan pendonasian di FISIPmaka dianggap tugas-tugas lain tidak perlu diketahui oleh aktor tersebut. Padahal dalam pembagian ranahdiawal pembentukan aliansi, BEM FISIP merupakan salah satu bagian dari aliansi gerakan melawan asap yang bertanggungjawab di ranah yang ketiga yaitu ranah donasi, yang seharusnya bertanggungjawab terkait dana yang didapatkan oleh aliansi melawan asap.

Ternyata setelah penulis telusuri, penyebabnya adalah faktor historis. Dimana antara BEM UI (yang notabene sebagai PIC dari aliansi gerakan melawan asap) dan BEM FISIP UI sering terjadi perbedaan pandangan terhadap suatu gerakan. Karena hubungan yang kurang harmonis tersebut sehingga membuat BEM FISIP terkesan "seperlunya" 
berkontribusi di aliansi gerakan melawan asap.

Terdapat nilai-nilai yang ditegakkan antara hubungan kerjasama BEM FISIP UI dengan aliansi gerakan melawan asap, nilai-nilai ini lebih kepada nilai- nilai yang umumnya terjadi antar organisasi yang melakukan suatu kerjasama seperti halnya nilai kepercayaan, nilai profesionalitas, tanggungjawab dan sebagainya. Nilai-nilai inilah yang Poucke (dalam Lukito 1995) katakan sebagai pengikat dalam memelihara keberlangsungan hubungan. Dapatdilihat pada bagan 2, jika digambarkan bentuk hubungan antara BEM FISIP UI dan SIAGA FISIP dengan aliansi melawan asap.

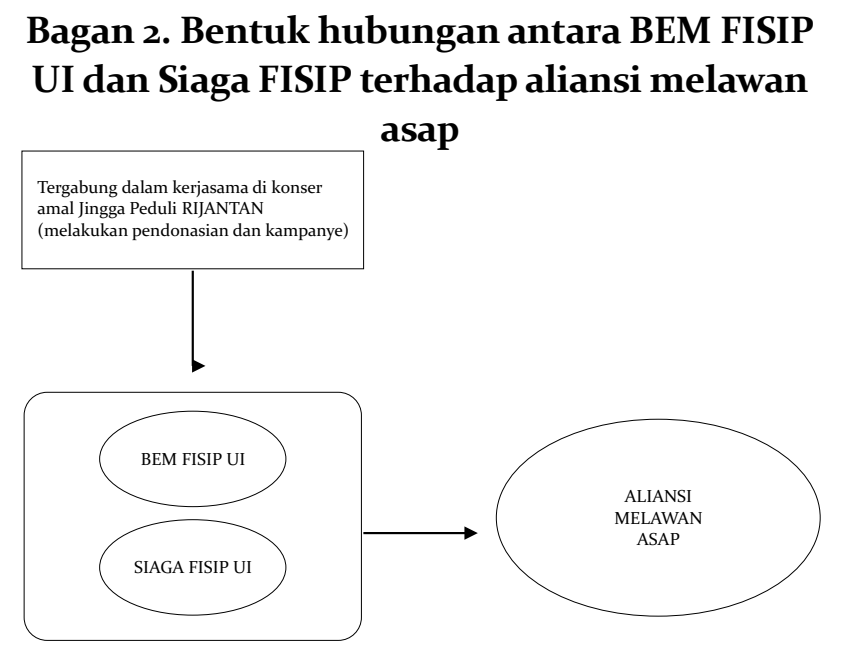

Jika dikaitkan dengan menggunakan 4 Pengukuran dari Solis (2011:326), maka dapat dikatakan audiens yang terpapar saat konser jingga peduli RIJANTAN lebih kurang sebanyak 200 orang. Sedangkan yang terpapar dari kampanye-kampanye yang di media sosial line lebih kurang 2.40oan orang, dan di media twitter 12.0ooan orang. Respon dari pengguna media sosial di Line cukup banyak, yang melakukan share sebanyak 129 akun, sedangkan yang melakukan like sebanyak 93 akun.

Followers di media sosial twitter sangat sedikit hanya 20 orang yang melakukan retweet dan 2 orang yang memberikan like. Penyebab dari sedikitnya followers yang merespon kampanye di media sosial tersebut samadenganpenyebabyangdialamiolehBEM UI dalam melakukan kampanye melawan asap di akun twitternya. Sehingga media Line justru menjadi media yang digunakan oleh BEM FISIP untuk mempublikasi kampanye melawan asap, meskipun mereka juga tetap memposting kampanye melawan asap di twitter. Memposting lewat media twitter tetap dilakukan karena mereka juga tidak menutup kemungkinan untuk mempublikasikannya ke masyarakat luar kampus UI sehingga mereka juga mengetahui kegiatan-kegiatan yang sedang dijalankan seperti kegiatan aksi melawan asap.

Seperti pernyataan Ali (pihak BEM FISIP) berikut:

"Ada, jadi kalo misalnya secara internal di FISIP atau si UI mungkin dampaknya nggak terlalu ya untuk penggunaan twitter. Tapi kan kita tetep publikasi ke masyarakat yang lebih luas lagi, dan pada kenyataannya masyarakat diluar sana tetep masih menggunakan Twitter ini. Kita tetep ada live tweet kok, meskipun udah rada tertinggal, kita tetep ada. Karena satu dua orang kan tetep masih ada aja yang baca. Sesimple orang re-tweet kan nggak jadi masalah gitu." (Ali, pihak BEM FISIP UI, wawancara pada tanggal 4 Desember 2015).

Dapat dikatakan bahwa aliansi gerakan melawan asap ini mendapatkan dana melebihi target awal, dimana awalnya aliansi menargetkan (memiliki tujuan) untuk mendapatkan donasi sebesar 10 juta namun pada kenyataannya mereka mendapatkan 50 juta. Penulis melihat bahwa hasil total donasi 50 juta ini tidak semata-mata digalang dengan caraonline atau menggunakan media sosial saja,melainkan hasil gabungan dari donasi atau sumbangan yang dikumpulkan dengan cara pemungutan langsung (offline) karena mereka juga melakukan kampanye dengan cara offline seperti pada konser amal jingga peduli rijantan dan juga aksi yang dilakukan di Bundaran HI. Sehingga sulit dikatakan bahwa donasi yang didapatkan karena peran dari kolaborasi yang terjadi antar organisasi yang tergabung dalam aliansi melawan asap di media sosial.

Selain itu, penulis juga sulit untuk 
mendapatkan data terkait dengan jumlah angka donasi yang hanya didapatkan melalui media sosial saja maupun jumlah angka donasi yang semata-mata didapatkan melalui pengumpulan dana secara langsung. Hal ini dikarenakan tidak terdapat bagian atau bidang tersendiri di aliansi melawan asap yang khusus menangani hal tersebut, sehingga semua donasi tersebut baik yang dikumpulkan dengan cara online maupun offlinedisatukan dalam satu rekening bersama atas nama aliansi melawan asap. Rekening aliansi ini dipegang oleh pihak BEM UI karena memang BEM UI sebagai penanggung jawab di aliansi melawan asap.

Jika mengacu pada Adianto (2011) dengan mengacu pada target yang didapatkan, dapat dikatakan bahwa kampanye melawan asap ini terbilang efektif karena tujuan kegiatan tersebut telah tercapai yaitu mendapatkan donasi bahkan melampaui target awal. Namun, jika dilihat dari peran dari beberapa jaringan organisasi yang terlibat seperti BEM FISIP dan SIAGA FISIP terhadap aliansi gerakan melawan asap lebih menunjukkan perandalammengefektifkankampanyeinidari cara offline bukan dukungan di media online khususnyadi media sosial. Sedangkan pihak Greenpeace lebih berperan mengefektifkan informasi-informasi yang diberikan ke pihak BEM UI seperti memberikan informasi terupdate dari titik asap langsung, dengan begitu membuat informasi yang dimuat di media sosial mempunyai tingkat kredibilitas yang tinggi karena bersumber langsung dari komunitas lingkungan (greenpeace) yang telah memiliki jam terbang yang cukup lama di lingkungan sertainformasiyang didapatkan langsung dari titik asap.

\section{SIMPULAN}

Aliansi gerakan melawan asap yang terbentuk atas dasar kepedulian terhadap suatu hal yang sama, yaitu kepedulian terhadap korban asap akibat pembakaran hutanyangilegalmemilikiaturanyangbersifat cair. Sehingga masing-masing dari organisasi dapat mengeksplore kemampuannya dalam memberikan kontribusi di aliansi melawan asap. Berdasarkan tujuan hubungan, terbentuk jaringan perasaan/sentiment antara BEM UI dan Greenpeace.

Jaringan yang hubungannya didasarkan pada jaringan perasaan/sentiment dapat memberikan doronganyang lebih untuk mengefektifkan kampanye karena memiliki isu, passion serta tujuan yang sama. Sedangkan bentuk hubungan yang terjadi antara BEM FISIP UI dengan aliansi melawan asap terbentuk jaringan interseksi antara hubungan perasaan/sentiment dengan hubungan kepentingan, dari tujuan hubungan jaringan ini membuat hubungan kerjasama dari kegiatan yang pernah dijalankan tidak berkelanjutan setelah tujuan kegiatan tersebut tercapai.

Beberapaorganisasiyang beradadibawah satu aliansi yang sama yaitu aliansi gerakan melawan asap, sistem kerja dari masingmasing organisasi terlihat mengkotak-kotak. Gerakan yang mereka lakukan dilaksanakan secara masing- masing, kalaupun organisasi lain membantu hanya bersifat sekadarnya. Hal ini dapat terjadi karena adanya kecenderungan bahwa kurang adanya momen-momen bersama yang diciptakan oleh aliansi melawan asap. Dari hal tersebut membuat masing-masing organisasi kurang terlihat solidaritasnya.

Belum berjalan dengan baiknya kampanye lingkungan di media sosial lebih disebabkan karena aktor yang membuat kampanye di media sosial kurang memahami targetkampanyenyasehinggadapatdikatakan "salah sasaran", yang membuat kurangnya respon aktif dari pengguna media sosial yang dipakai tersebut. Dengan demikian penulis kira perlu adanya pemetaan sasaran objek yang akan dipaparkan dengan suatu kampanyeyang ingin disebarluaskandi media sosial. Selain memberikan efisiensi kerja, dampak lainnya juga dapat mengefektifkan kegiatan yang akan dilaksanakan.

Kampanye dengan media social lebih efektif, terlebih dengan bantuan orang lain. Tetapi dapat dilihat bahwa ternyata kalau untukdimediaonline-nyasendiribelumdapat diketahui seberapa banyak peningkatan yang terjadi dari kerjasama yang dilakukan dengan 
jaringannya aliansi melawanasap. Akan tetapi dapat kita lihat bahwa dengan jaringan ada kelebihan lain yang diperoleholeh aliansi, terutama pada tujuan hubungan jaringan sentiment bahwasanya dengan kepedulian yg samadapat menjadi pendorong untuk ikut bersama-sama mengusung isu yang mereka minati bersama.

\section{DAFTAR PUSTAKA}

Agusyanto, Ruddy. 2014. Jaringan Sosial Dalam Organisasi (Edisi Revisi). Jakarta: P.T Raja Grafindo Persada.

Ardianto, Elvinaro. 2001. "Public Relations on the Net: Sebuah Perspektif Baru Humas" Mediator, Vol. 2 No.1

Darsono, Febryandi. 2011. "Koalisi Ornop Pasca Orde Baru: Studi tentang Jaringan Walhi dalam Kampanye Isu Hutan." MASYARAKAT:JurnalSosiologi, Vol. 16, No. 1, Januari 2011.

Kapriani, Dea Rizki dan Lubis, Djuana P. 2014. "Efektifitas Media Sosial untuk Gerakan Sosial Pelestarian Lingkungan." Jurnal Sosiologi Pedesaan, Desember 2014:187200

Lailia, Anita Nur. 2014. "Gerakan Masyarakat dalam Pelestarian Lingkungan Hidup (studi tentang upaya menciptakan kampung hijau di kelurahan gundih surabaya)." Jurnal Politik Muda, Agustus-Desember, 283-302

Lesmana, I Gusti Ngurah Aditya. 2012. "Analisis Pengaruh Media Sosial Twitter Terhadap Pembentukan Brand Attachment (Studi: PT. XL.Axiata)." Tesis Program Magister Manajemen Fakultas Ekonomi. Diunduh pada 30 Desember 2015

Loisa, Riris. 2011. "Jejaring sosial, identitas kolektif dan aksi politik. Faktor facebook dalam revolusi Mesir." Jurnal komunikasi Universitas Tarumanegara. Tahun III/o1/2011. Diunduh pada 27 Agustus 2015

Lukito.Rijanto P. 1995. "Jaringan-Jaringan Sosial dalam Organisasi PAM DKI Jakarta: pelayanan air minum DKI Jakarta dalam rangka ketahanan nasional". Tesis Kajian Ketahanan Nasional Universitas Indonesia.

Maryati."Ratusan warga berburu sampah plastik di Jakarta." Antara News 23 Februari 2014. <http://www. antaranews.com/berita/420524/ 
ratusan-warga-berburu-sampahplastik-di-jakarta>. Diakses pada 21 September 2015

Oktavianti, Meria. 2014. "Alur Pesan Kampanye Gerakan Cikapundung Bersih dalam Meningkatkan Kesadaran Kebersihan Lingkungan.” Jurnal Komunikasi Universitas Tarumanegara, Tahun VI/o2

Solis, Brian. 2011. Engage! The Complete Guide for Brands and Businesses to Build, Cultivate and Measure Success in The New Web. John Wiley \&Sons. New Jersey.

Syamsul, FakhyarRusyid.2014. "IklanLayanan Masyarakat Kampanye Lingkungan Hidup "Ruang Terbuka Hijau".Skripsi Ilmu Komunikasi FISIP Universitas Hasanuddin.
Sujatmiko, Iwan Gardono. 2014. "Keterwakilan Etnis di Politik Nasional: Kasus Etnis Sunda di Republik Indonesia." MASYARAKAT:Jurnal Sosiologi, Vol. 19, No. 1, Januari

Widorini, Wahyu Yuliastuti. 2014. "Strategi Komunikasi Earth Hour dalam Kampanye Gaya Hidup Ramah Lingkungan”.eJurnal Mahasiswa Universitas Sebelas Maret. Diunduh pada 24 Agustus 2015

William Lawrence Neuman, 2004. Social Research Methods: Qualitative and quantitative Approaches: Boston: Allyn dan Bacon 